\title{
Does body size of neotropical ant species influence their recruitment speed?
}

\author{
Bruno Spacek Godoy ${ }^{1,3}$ \& Lucas Marques de Camargos $^{2}$ \\ ${ }^{1}$ Núcleo de Ciências Agrárias e Desenvolvimento Rural, Universidade Federal do Pará - UFPA, \\ Rua Augusto Corrêa, 01, Campus Universitário do Guamá, CEP 66075-110, Belém, PA, Brasil \\ ${ }_{2}^{2}$ Programa de Pós-graduação em Entomologia - PPG-ENT, Instituto Nacional de Pesquisas da \\ Amazônia - INPA, Av. André Araújo, 2936, Petrópolis, CP 2223, CEP 69080-971, Manaus, AM, Brasil \\ ${ }^{3}$ Corresponding author: Bruno Spacek Godoy, e-mail: bspacek@gmail.com
}

GODOY, B.S. \& CAMARGOS, L.M. Does body size of neotropical ant species influence their recruitment speed? Biota Neotrop. 13(1): http://www.biotaneotropica.org.br/v13n1/en/abstract?article+bn02013012013

\begin{abstract}
Ants are one of the most important animal groups in tropical forests because of its abundance and number of species. An important characteristic of the group is the eusociality, which allows the occurrence of a recruitment behavior when food resource is found. However, there are two main questions regarding this behavior: (i) the recruitment is a product of environmental or phylogenetic pressures, and (ii) the recruitment speed is related to the body size of the ant species. In this work we addressed these two questions using 17 species of neotropical ants, in the Amazonic lowland dense rain forest. According to results, recruitment behavior is related to ant size, where smaller species exhibit this trait when finding a protein resource. However, species size is not important in recruitment speed, which suggests that speed can be best explained by the type of food resources needed in the ant colony.
\end{abstract}

Keywords: formicidae, foraging behavior, phylogenetic contrasts, social insects, Amazon.

GODOY, B.S. \& CAMARGOS, L.M. O tamanho corpóreo de espécies de formigas neotropicais influencia na velocidade de recrutamento? Biota Neotrop. 13(1): http://www.biotaneotropica.org.br/v13n1/pt/ abstract?article+bn02013012013

Resumo: Formigas são um dos mais importantes grupos animais nas florestas tropicais devido a sua abundância e seu número de espécies. Uma característica importante do grupo é a eusocialidade, que permite a ocorrência do comportamento de recrutamento quando um recurso alimentar é encontrado. Entretanto, existem duas questões principais acerca desse comportamento: (i) o recrutamento é um produto de pressões ambientais ou filogenéticas, e (ii) a velocidade de recrutamento é relacionada ao tamanho corpóreo das espécies de formigas. Neste trabalho nós analisamos essas duas questões em 17 espécies de formigas neotropicais, na floresta Amazônica densa de terras baixas. De acordo com os resultados, o recrutamento é fortemente relacionado com o tamanho da formiga, sendo que espécies menores exibem essa característica quando encontram uma fonte protéica. Entretanto, o tamanho das espécies não é importante na velocidade de recrutamento, o que sugere que a velocidade de recrutamento pode ser melhor explicado pelo tipo de recursos alimentares necessários à colônia.

Palavras-chave: formicidae, comportamento de forrageio, contrastes filogenéticos, insetos sociais, Amazônia. 


\section{Introduction}

In tropical forests, one of most important taxonomic group within Insecta, in numbers of individuals, species richness and ecological dynamics, are the ants (Hölldobler \& Wilson 1990). Formicidae comprises more than 12,500 species, but studies suggest that total ant diversity could well exceed 25.000 species, of which $30 \%$ is found in the Neotropical region, making it the richest region in the world (Fernández \& Sendoya 2004, Ward 2010). An important characteristic of the group is that all species are eusocial, exhibiting cooperative parental care, overlapping generations and reproductive division of labor (Oster \& Wilson 1978, Trivers 1985). In social insects, cooperation significantly improves the foraging efficiency at colony level, reducing total energy costs and the risks of individual predation (Oster \& Wilson 1978, Schmidhempel 1991).

In general, an ant colonies need food with different protein and carbohydrate concentrations for each individual: protein-rich food for larvae and queens, and carbohydrate-rich food for the workers (Hölldobler \& Wilson 1990). When the ants are searching for food, they may exhibit three distinct behaviors: (a) recruit other workers to dominate and transport the food, (b) carry the resource itself, or (c) ignore the food. Among recruiter species, behavior may also vary, with the ants continuously following in line, many ants walking towards the resource without following in row or a few ants being recruited per time (Hölldobler \& Wilson 1990, Ingram 2002).

The decision made by an ant when locating a resource is to maximize the energy balance, in order to obtain a higher gain at low energetic cost for obtaining food, as predicted by the optimal foraging theory (Sih 1982a,b, Stephens \& Krebs 1986). Due to restrictions on dominating and carrying resources, small ants should recruit other ants to ensure their domination after encountering a resource, avoiding the loss of that resource to a larger ant, or other animals (PearceDuvet \& Feener Junior et al. 2010). Additionally, the recruitment speed is directly related to the amount of resources that an ant can carry. Therefore small ants should recruit faster than larger ants, since the smaller body size is satisfied quickly. The speed of food sources recruitment can be an important determinant of ant's communities, since the evolutionary trade-off between exploitative and interference competition may be a key influence to the dominance of resources (Davidson 1998, Parr \& Gibb 2012).

The different mechanisms to recruit individuals from the colony to gather the food resource, especially those with chemical, visual or mechanical stimulations (Oster \& Wilson 1978), support the hypothesis that this feature has several different origins, generated by various ecological processes (Wilson \& Hölldobler 2005). So, recruitment in phylogenetic distant ants may have evolved due to ecological needs through the process of convergent evolution, having no relation to the ancestry group (Futuyma 1986). Thus, when analyzing related groups with similar characteristics, the effect of phylogenetic relationships must be removed in order to discern whether the feature in question is due to ecological processes or common ancestry (Westoby et al. 1995a, Diniz-Filho 2000).

Species and other taxonomic units would not be independent observations in statistical analysis (Felsenstein 1985), and the manly source of dependence between species is their phylogenetic relationship or phylogenetic autocorrelation (Garland Junior et al. 2005, Martins et al. 2002, Martins \& Garland 1991). Phylogenetic signs can be correlated with ecological similarity between species pairs, and this lack of phylogenetic history independence generates bias in ecological analysis affecting the statistical Type I error (Martins et al. 2002). Another advantage in using phylogenetic signs on ecological hypothesis testing is the possibility to observe if a characteristic follows other traits in a clade's evolutionary history (Westoby et al. 1995b, Harvey 1996, Hansen \& Martins 1996).

This study aims to test the hypothesis that the recruitment by ants to gather a protein source is restricted to species of smaller body size. If true, a second hypothesis to be tested is whether there is negative relationship between size of the workers and recruitment speed, since the smaller ants need to quickly handle food resources before competitors take it.

\section{Materials and Methods}

\section{Study area}

The study was conducted in August 2005 at the Kilômetro 41 reserve $\left(2^{\circ} 24^{\prime} \mathrm{S}\right.$ and $\left.59^{\circ} 44^{\prime} \mathrm{W}\right)$, a continuous forest belonging to the Biological Dynamic Project of Forest Fragments (BDPFF) in central Amazon. The altitude varies between 50 and $150 \mathrm{~m}$ above sea level, featuring plateau, slope and lowland areas, with precipitation between 1900 and $2500 \mathrm{~mm}$ per year and dry season from June to October (Lovejoy 1986, 1999).

\section{Sampling}

There was no previous selection of the ant species and colonies sampled. Several environments were previously visited in order to detect different ant colonies for this study, and only one colony for each species was observed. To test which species recruits or not, a protein bait consisting of a $10 \mathrm{~mm}^{2}$ piece of cheese was offered to workers, placed at a fixed distance of $50 \mathrm{~cm}$ from the colony. The behavior of the ant was observed after placing the bait. If the other ants left the colony in the bait direction after the worker had returned to the nest, this species was classified as recruiter. When an ant left the bait in the way to the colony, recruitment time began to be measured, and stopped when other ants came out and moved towards the resource after the first individual had entered the nest. This procedure was repeated three times per nest in different days, and in each experiment, the bait was placed keeping the same radius distance from the nest, however, in different directions. Bait placement in each test depended on the ant behavior. For terrestrial species the bait was placed on the ground and for the arboreal ones, it was placed over the vegetation or attached to trees with pins.

A minimum of five workers of each ant species were sampled for subsequent total body length measurement. Workers of all species were measured, but in species with length polymorphism, the other castes were not measured. At the laboratory the ants were identified to genus and when possible to species, or separated into morphospecies (Fernández 2003).

\section{Data analysis}

All analyses were performed using the R statistical software (R Development... 2011). Average species sizes were categorized into large and small, depending on whether they were larger or smaller than the total median. This categorization was necessary because the method used to analyze the dependency between two features (in this case, size and occurrence of recruitment) in a phylogeny is done by comparing two variables (Pagel 1994).

Size data and recruitment of ant species occurrence were optimized as additive characters in the phylogenetic tree proposed by Astruc et al. (2004) for the subfamilies of Formicidae. This tree was used because it presents much of the genera found in the study area, reducing the number of artificial inclusion in the tree, and consequently the number of polytomies (Bolton 1995). No external group was used to polarize the characters. To test whether the size of the species is related to recruitment occurrence, state changes of 
these characters were observed on the tree and analyzed with the Fisher's exact test, as described by Burt (1989).

The distance traveled by ants was standardized by dividing the length traveled from bait to nest $(50 \mathrm{~cm})$ by the species average size. Then standardized distance was also divided by the time (in seconds) the ant spent moving, resulting in a speed ratio which represented how often an ant can move its body length per second. The values of standardized ant speed, and species size were analyzed using phylogenetic contrasts (Diniz-Filho 2000) based on the same phylogenetic group, using the methodology of Purvis \& Garland (1993) to solve polytomies. Contrast analysis assumes that although the characteristic values observed in the species are interdependent, their differences are a product only of the divergence time in evolutionary history. Thus, in the analysis, $n-1$ independent contrasts were calculated on the evolutionary group history, using the difference between $n$ species and ancestor values (phylogenetic nodes). Finally, the values used in the correlation and/or on other tests, are the contrasts of the characteristic of interest, previously obtained. As branch-length values were not available for all genera, the value of 1 was the standard value for the terminal taxa, and for ancestral branches a correction calculation was made (Diniz-Filho 2000). With this methodology it was possible to analyze the correlation of ant size and recruitment speed, through a simple linear regression, without the effect of phylogenetic dependence. The subfamily Myrmicinae was the only used in this analysis because it had more than one recruiter species and variation in recruitment rate.

\section{Results}

We found 17 morphospecies distributed in 13 genera and six subfamilies. The most well represented subfamily was Myrmicinae with eight morphospecies in four genera (Table 1). The subfamilies Myrmicinae, Formicinae and Dolichoderinae presented morphospecies that recruit and that do not recruit. The minimum and maximum values of body size of the species were 1.3 and $11.0 \mathrm{~mm}$ for Solenopsis sp. Westwood 1840 and Dolichoderus sp. Lund 1831 respectively, with a median of $4.4 \mathrm{~mm}$. Since Camponotus sp. Mayr 1861 had an average size equal to the species median, it was categorized as both small and large, separately, for data analysis, in order to test the effect of this choice.

The phylogeny with optimized characters (Figure 1) showed that body size was originally large, with two independent changes: a group that unites Pheidole sp. Westwood 1839, Crematogaster limata Smith 1858, Crematogaster tenuicula Forel 1904 (Crematogaster Lund 1831) species and Solenopsis sp., and other in Azteca sp. Forel 1878 species. Relative to the occurrence of recruitment, the basal phylogeny trait is not recruitment, even recruitment having

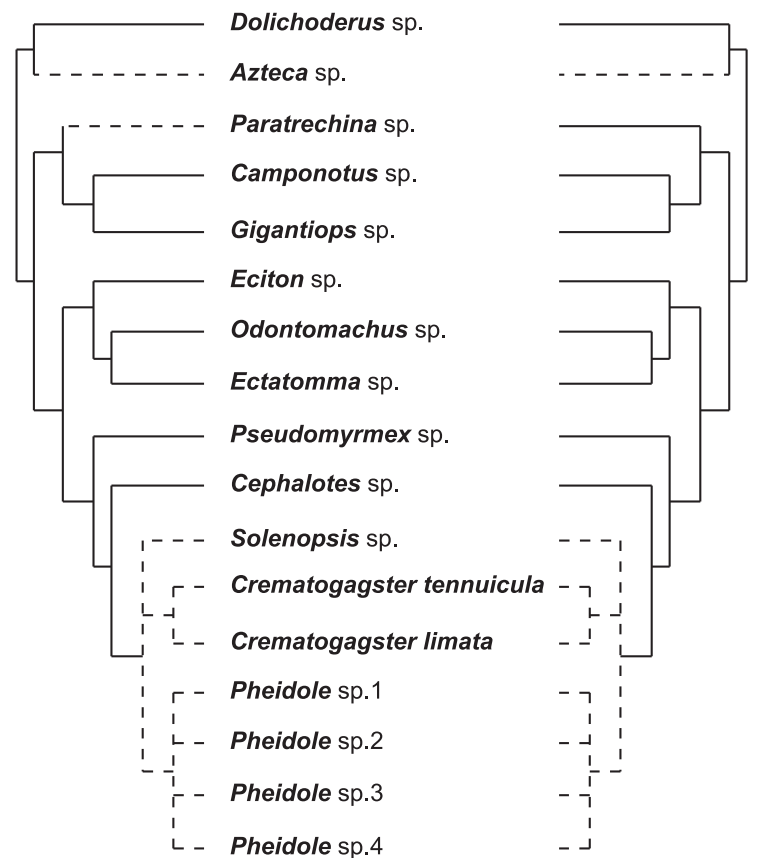

Figure 1. Phylogeny of Formicidae proposed by Astruc (2004) showing the evolution of traits. The branches of the left side represent change in the recruitment character as the continuous line represents the non-recruitment and the dotted line represents recruitment behavior. The right side represents the character size, large as the continuous line and small as the dotted.

Table 1. Morphospecies of ants collected in the Kilômetro 41 reserve and their measured characteristics.

\begin{tabular}{|c|c|c|c|c|}
\hline Subfamily & Taxon & Speed recruitment* & Size/N** & Size categorized \\
\hline Pseudomyrmecinae & Pseudomyrmex sp. & Not recruit & $5,3 / 6$ & Big \\
\hline \multirow[t]{8}{*}{ Myrmicinae } & Pheidole sp.1 & 3,3 & $2,4 / 7$ & Small \\
\hline & Pheidole sp.2 & 2,0 & $3,0 / 8$ & Small \\
\hline & Pheidole sp.3 & 2,1 & $3,0 / 7$ & Small \\
\hline & Pheidole sp.4 & 3,5 & $2,7 / 8$ & Small \\
\hline & Crematogaster limata & 5,5 & $2,7 / 10$ & Small \\
\hline & Crematogaster tennuicula & 3,7 & $2,6 / 7$ & Small \\
\hline & Solenopsis sp. & 5,3 & $1,3 / 9$ & Small \\
\hline & Cephalotes sp. & Not recruit & $7,6 / 5$ & Big \\
\hline Ecitoninae & Eciton sp. & Not recruit & $6,6 / 8$ & Big \\
\hline \multirow[t]{2}{*}{ Ponerinae } & Ectatomma sp. & Not recruit & $8,9 / 5$ & Big \\
\hline & Odontomachus sp. & Not recruit & $10,8 / 9$ & Big \\
\hline \multirow[t]{3}{*}{ Formicinae } & Paratrechina sp. & Recruit $^{\mathrm{a}}$ & $4,8 / 6$ & Big \\
\hline & Gigantiops destructor & Not recruit & $9,8 / 5$ & Big \\
\hline & Camponotus sp. & Not recruit & $4,4 / 6$ & b \\
\hline \multirow[t]{2}{*}{ Dolichoderinae } & Azteca sp. & 1,3 & $2,6 / 9$ & Small \\
\hline & Dolichoderus sp. & Not recruit & $11,0 / 5$ & Big \\
\hline
\end{tabular}

*Speed in ants.seconds ${ }^{-1}$.**N is the number of individuals measured $\mathbf{a}$ - It was observed that the species recruited, however, as the nest was located in the canopy, its speed was not measured. b-Species Camponotus sp. was analyzed with two sizes. 
independently appeared three times in the basal group that unites all Myrmicinae, except Cephalotes sp. Latreille 1802, in Paratrechina sp. Motschulsky 1863, in the group that unites it to Gigantiops destructor (Fabricius) 1804 (Gigantiops Roger 1863) and Camponotus sp, and the group of the Dolichoderinae Azteca sp. morphospecies (Figure 1). There was a relation between changes in body size and recruitment (Fisher's exact test $p=0.005$ with Camponotus sp. categorized as large, and $p=0.04$ when categorized as small), indicating concordance in the phylogenetic change. The regression between contrasts of recruitment speed and species size (Table 2) was not significant $\left(r^{2}=0.32, \mathrm{~F}=3.48, \mathrm{DF}=1\right.$ and $4, \mathrm{p}=0.91$, Figure 2$)$.

\section{Discussion}

The ultimate cause of life diversity is evolution. It is responsible to, from the origin of species, to the variety of ecological, physiological, morphological and behavioral traits that those species possess (Wiens et al. 2010). Only the direct examination of ecological characters distribution on a phylogeny can provide evidences of separation in ecological or niche conservation process (Kelly et al. 2008). The observed trait in this study, the foraging behavior in ant species, was originated by ecological pressures in the family history. This pattern is supported in this work by observing the combined changes of body size and foraging behavior in the phylogenetic tree.

In this study, ant size was important for its foraging behavior, where small species recruit while large ones do not, a pattern which has been reported in other studies (Davidson 1998). This pattern can be explained by different foraging area sizes. Larger ants typically have large foraging areas (Hughes et al. 2002, Davidson et al. 2003), often practicing unfeasible recruitment because energy expenditure and time spent by the worker to return and recruiting would be higher,

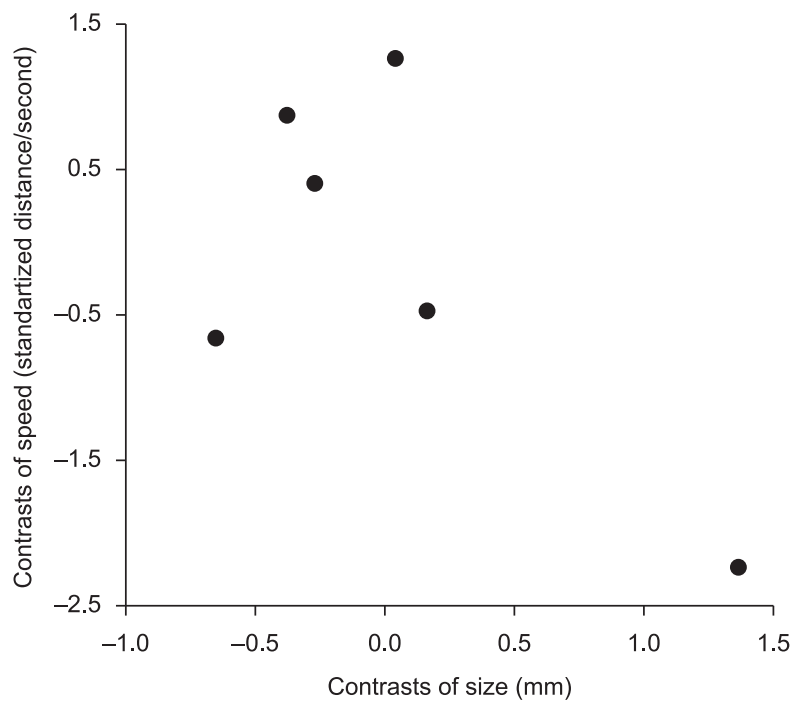

Figure 2. Relationship between the contrasts for size and speed recruitment of species of Myrmicinae collected in the Kilometro 41 reserve, Amazonas. and having negative influence on the energy balance. Furthermore, individual size reduction can be a gain for the colony, via an investment in a larger number of ants. A large number of individuals enable a more intense foraging action in the resource searching area and a greater availability of ants that can work together, possibly allowing recruitment (Dejean et al. 1999). Moreover, the reduction in body size allowing the increase of ants in the nest is an ecological advantage for species with reduced ability to find food, as the rate of resource discovery is directly related to the number of foraging individuals (Pearce-Duvet et al. 2011a).

These results are consistent with the optimal foraging theory, where energy balance tends to be positive for small ants when they recruit, but negative for larger ones that exhibit the same behavior, due to a low density of workers near the colony (Cole \& Wiernasz 2002, Heller \& Gordon 2006, Folgarait et al. 2007). Besides this energetic advantage for small ants, recruiting offers other advantages, such as numerical superiority over their competitors, and the possibility of handling resources larger than the individuals' body size (Hölldobler \& Wilson 1990).

Despite the tendency of the recruitment to occur by smaller ants, its speed rate is not influenced by species size. The species exclusion in the analyses, because of the lack of phylogenetic and taxonomic information about the neotropical ant species, like Dolichoderinae subfamily, specially the rich Azteca genera (Longino 2007), may have affected the results, disallowing a precise parameters estimation in regression analyses by the smaller number of observations. However, the fitted relationship with contrasts of these traits showed a negative tendency (Figure 2). This trend is inconsistent with other results. In a meta-analysis covering 24 ant species, the body size is an important factor to determine the speed of individuals (Hurlbert et al. 2008). The only difference is the non-use of comparative phylogenetic methods in analyses, allowing a substantial data variation, maintained without explanation.

The influence of starvation on the ant colony was studied in the evaluation of behavioral changes in recruitment through changes in the chemical signals as well as changes in the quantity and quality of collected food (Hangartner 1969, Josens \& Roces 2000). For many consumers, to efficiently obtain energy may be less critical than to obtain a specific constituent of the diet, which in this case makes the theory of optimal foraging limited in its predictions (Stephens \& Krebs 1986, Sih \& Christensen 2001). The nutritional needs of each colony at the time of the experiment can explain the absence of relationship in the size and speed recruitment in Mirmicinae species (Davidson et al. 2003). The bait offered to ant workers in the experiment was a protein based resource, but the colony food requirements consist of many other resources (Cook et al. 2010, Pearce-Duvet \& Feener Junior 2010). The type of food bait can also be detected by the ants before they find it, allowing them to speed up to capture the most needed resource (Pearce-Duvet \& Feener Junior 2010). Thus, the speed of recruitment may be a response of a specific resource type and the momentary necessity of the colony.

Table 2. Contrasts for the speed of recruitment and size of species and morphospecies of Myrmicinae collected in the Kilômetro 41 reserve.

\begin{tabular}{lcc}
\hline \multicolumn{1}{c}{ Contrasts } & Speed recruitment \\
\hline Pheidole sp.1 + Pheidole sp.2 & 0,88 \\
Pheidole sp.1 e 2 + Pheidole sp.3 & 0,42 \\
Pheidole sp.1,2 e $3+$ Pheidole sp.4 & $-0,38$ \\
Pheidole + Solenopsis & $-0,27$ \\
Crematogaster limata + Crematogaster tennuicula & 0,16 \\
Pheidole e Solenopsis + Crematogaster & $-2,23$ & 1,26 \\
\hline
\end{tabular}


An alternative hypothesis to recruitment time would be that the speed that an ant is able to reach is related to other features, beyond simply body size. At very high speeds, the ant needs large energy expenditure to maintain inertia, and a more robust temperature control (Angilletta et al. 2008). This reason leads the ants to adopt a random walk, as the tortuous path allows maintenance of a lower speed, but with a greater chance of predation escape and discovery other resource sources (Pearce-Duvet et al. 2011a). The maximum speed of the organisms varies greatly between individuals in account of genetic reasons or environmental differences, interfering in the search for an explicit standard in accordance with the theory of energy balance (Huey et al. 1989). Some ants also have species specific searching patterns, and having this feature as an important component of niche separation (Pearce-Duvet et al. 2011b).

In fact, organisms rarely use the maximum speed under natural conditions (Hertz et al. 1988, Irschick 2000, Braña 2003), once the maximum speed is determined not only by an ecological process, as simple as competition, but rather by an interaction of factors such as physiology, conflicting demands for resources and biotic interactions. Also, the roughness of the substrate can slow down the foraging speed, since the land relief increases the total distance traveled by the ant (Bernadou et al. 2011). However, that variable was not measured in the execution of our research, serving as a posteriori explanation for the observed pattern.

The recruitment to protein based resource and the size of ant species are related in central Amazon forest. The ecological pressure is the most acceptable explanation for this pattern since the recruitment trait arose many times in the phylogenetic ant history. Avoiding competition with larger species and maintaining a positive energy capture balance are important factors to determine the evolution of this characteristic. However, recruitment speed was not associated with the specie size. The comprehension of behavior differences in food foraging is important to explain the functional and diverse distribution of ant species (Mertl et al. 2010). Small species are usually more abundant and active than the larger ones, which makes them an important link on forest functionality. Foraging behavior has long been considered key to understanding communities' structures. However, the way in which species compete to discover food has largely been ignored. Instead, species differences in speed or recruitment behavior are determined by the nests' needs and energetic balance. Thus, the use of a large number of individuals can be an advantage to smaller species. Indeed, they may form the basis for the trade-offs that mediate species coexistence, small individuals with efficient recruitment or large individuals with solitary foraging behavior.

\section{Acknowledgements}

We thank Glauco Machado and Henrique Nascimento, coordinators of the Ecology of the Amazon Forest's Field Course and all students/friends from the 2005' class. We are also grateful to Adalberto José and Thiago Izzo for reviewing the manuscript and giving valuable suggestions. We are grateful to Rafael Chiamenti for the help with Figure 1.

\section{References}

ANGILLETTA, M.J., ROTH, T.C., WILSON, R.S., NIEHAUS, A.C. \& RIBEIRO, P.L. 2008. The fast and the fractalous: speed and tortuosity trade off in running ants. Functl. Ecol. 22(1):78-83.

ASTRUC, C., JULIEN, I., ERRARD, C. \& LENOIR, A. 2004. Phylogeny of ants (Formicidae) based on morphology and DNA sequence data. Mol. Phylogenet. Evol. 31(3):880-893. PMid:15120386. http://dx.doi. org/10.1016/j.ympev.2003.10.024
BERNADOU, A., ESPADALER, X., DOS-REIS, V. \& FOUCARSSIÉ, V. 2011. Effect of substrate roughness on load selection in the seedharvester ant Messor barbarous L. (Hymenoptera, Formicidae). Behav. Ecol. Sociobiol. 65(9):1763-1771. http://dx.doi.org/10.1007/s00265011-1184-4

BOLTON, B. 1995. A Taxonomic and Zoogeographical Census of the Extant Ant Taxa (Hymenoptera, Formicidae). J. Nat. Hist. 29(4):1037-1056. http://dx.doi.org/10.1080/00222939500770411

BRAÑA, F. 2003. Morphological correlates of burst speed and field movement patterns: the behavioural adjustment of locomotion in wall lizards (Podarcis muralis). Biol. J. Linn. Soc. 80(1):135-146. http://dx.doi. org/10.1046/j.1095-8312.2003.00226.x

BURT, A. 1989. Comparative methods using phylogenetically independent contrast. Oxford Surv. Evol. Biol. 6: 33-54.

COLE, B.J. \& WIERNASZ, D.C. 2002. Recruitment limitation and population density in the harvester ant, Pogonomyrmex occidentalis. Ecology. 83(5):1433-1442. http://dx.doi.org/10.1890/00129658(2002)083[1433:RLAPDI]2.0.CO;2

COOK, S.C., EUBANKS, M.D., GOLD, R.E. \& BEHMER, S.T. 2010. Colony-level macronutrient regulation in ants: mechanisms, hoarding and associated costs. Anim. Behav. 79(2):429-437. http://dx.doi.org/10.1016/j. anbehav.2009.11.022

DAVIDSON, D.W. 1998. Resource discovery versus domination in ants: a functional mechanism for breaking the trade-off. Ecol. Entomol. 23(4):484-490. http://dx.doi.org/10.1046/j.13652311.1998.00145.x

DAVIDSON, D.W., COOK, S.C., SNELLING, R.R. \& CHUA, T.H. 2003. Explaining the abundance of ants in lowland tropical rainforest canopies. Science. 300(5621):969-972. PMid:12738862. http://dx.doi.org/10.1126/ science. 1082074

DEJEAN, A., SCHATZ, B. \& KENNE, M. 1999. How a group foraging myrmicine ant overwhelms large prey items (Hymenoptera: Formicidae) Sociobiology 34(3):407-418.

DINIZ-FILHO, J.A.F. 2000. Métodos Filogenéticos Comparativos. Holos Editora, São Paulo, Brazil

FELSENSTEIN, J. 1985 Confidence limites on phylogenies: an approach using the bootstrap. Evolutionary Anthropology. 39:783-791.

FERNÁNDEZ, F. 2003. Introducción a las Hormigas de la región Neotropical. Instituto de Investigación de Recursos Biológicos Alexander von Humboldt, Bogotá, Colombia.

FERNÁNDEZ, F. \& SENDOYA, S. 2004. Synonymic list of Neotropical ants (Hymenoptera: Formicidae). Biota Colomb. 5(1):3-105.

FOlgARAIT, P.J., GOROSITO, N., PIZZIO, R., ROSSI, J.P. \& FERNANDEZ, J. 2007. Camponotus punctulatus ant's demography: a temporal study across land-use types and spatial scales. Insect. Soc. 54(1):42-52. http://dx.doi.org/10.1007/s00040-007-0906-0

FUTUYMA, D.J. 1986. Evolutionary Biology. Sinauer Associates, Massachusetts. PMid:11611994.

GARLAND JUNIOR, T., BENNETT, A.F. \& REZENDE, E.L. 2005 Phylogenetic approaches in comparative physiology. The Journal of Experimental Biology. 208:3015-3035. PMid:16081601. http://dx.doi. org/10.1242/jeb.01745

HANSEN, T.F. \& MARTINS, E.P. 1996 Translating between microevolutionary process and macroevolutionary patterns: the correlation structure of interspecific data. Evolution. 50:1404-1417. http://dx.doi. org/10.2307/2410878

HANGARTNER, W. 1969. Structure and Variability of Individual Odor Trail in Solenopsis Geminata Fabr. (Hymenoptera Formicidae). Z. Vergl. Physiol. 62(1):111-120. http://dx.doi.org/10.1007/BF00298046

HARVEY, P.H. 1996. Phylogenies for ecologists. J. Anim. Ecol. 65(3):255-263. http://dx.doi.org/10.2307/5872

HELLER, N.E. \& GORDON, D.M. 2006. Seasonal spatial dynamics and causes of nest movement in colonies of the invasive Argentine ant (Linepithema humile). Ecol. Entomol. 31(5):499-510. http://dx.doi. org/10.1111/j.1365-2311.2006.00806.x 
HERTZ, P.E.; HUEY, R.B.; GARLAND, T. 1988. Time Budgets, Thermoregulation, and Maximal Locomotor Performance - Are Reptiles Olympians Or Boy Scouts. Am. Zool. 28:927-938.

HÖLLDOBLER, B.; WILSON, E.O. 1990. The Ants. Springer Verlag, Berlim, 746p.

HUEY, R.B., NIEWIAROWSKI, P.H., KAUFMANN, J. \& HERRON, J.C. 1989. Thermal Biology of Nocturnal Ectotherms - Is Sprint Performance of Geckos Maximal at Low Body Temperatures. Physiol. Zool. 62:488-504.

HUGHES, W.O.H., EILENBERG, J. \& BOOMSMA, J.J. 2002. Trade-offs in group living: transmission and disease resistance in leaf-cutting ants. P. Roy. Soc. Lond. B. Bio. 269(1502):1811-1819. PMid:12350269 PMCid:1691100. http://dx.doi.org/10.1098/rspb.2002.2113

HURLBERT, A.H., BALLANTYNE, F. \& POWELL, S. 2008. Shaking a leg and hot to trot: the effects of body size and temperature on running speed in ants. Ecol. Entomol. 33(1):144-154. http://dx.doi.org/10.1111/j.13652311.2007.00962.x

INGRAM, K.K. 2002. Plasticity in queen number and social structure in the invasive Argentine ant (Linepithema humile). Evolution 56(10):2008-2016. PMid: 12449488.

IRSCHICK, D.J. 2000. Comparative and behavioral analyses of preferred speed: Anolis lizards as a model system. Physiol. Biochem. Zool. 73(4):428-437. PMid:11009396. http://dx.doi.org/10.1086/317733

JOSENS, R.B. \& ROCES, F. 2000. Foraging in the ant Camponotus mus: nectar-intake rate and crop filling depend on colony starvation. J. Insect Physiol. 46(7):1103-1110. http://dx.doi.org/10.1016/S00221910(99)00220-6

KELLY, C.K., BOWLER, M.G., PYBUS, O. \& HARVEY, P. 2008. Phylogeny, niches, and relative abundance in natural communities. Ecology 89(4):962-970. PMid:18481521. http://dx.doi.org/10.1890/070322.1

LONGINO, J.T. 2007. A taxonomic review of the genus Azteca (Hymenoptera: Formicidae) in Costa Rica and a global revision of the aurita group. Zootaxa 31(1491):1-63.

LOVEJOY, T.E. 1986. Biological Diversity. Issues Sci. Technol. 2:13.

LOVEJOY, T.E. 1999. Ecology and management of fragmented tropical landscapes - Preface. Biol. Conserv. 91(1-2):99. http://dx.doi.org/10.1016/ S0006-3207(99)00130-5

MARTINS, E.P., DINIZ-FILHO, J.A.F. \& HOUSWORTH, E.A. 2002 Adaptive constraints and the phylogenetic comparative method: a computer simulation test. Evolution. 56:1-13. PMid:11913655.

MARTINS, E.P. \& GARLAND, T. 1991 Phylogenetic Analyses of the Correlated Evolution of Continuous Characters - A Simulation Study. Evolution. 45:534-557. http://dx.doi.org/10.2307/2409910

MERTL, A.L., SORENSON, M.D. \& TRANIELLO, J.F.A. 2010. Communitylevel interactions and functional ecology of major workers in the hyperdiverse ground-foraging Pheidole (Hymenoptera, Formicidae) of Amazonian Ecuador. Insect. Soc. 57(4):441-452. http://dx.doi. org/10.1007/s00040-010-0102-5

OSTER, G. \& WILSON, E.O. 1978. Caste and Ecology in the Social Insects. Princeton University Press, Princeton, 372p.

PAGEL, M. 1994. Detecting correlated evolution on phylogenies: a general method for the comparative analysis of discrete characters. Proc. R. Soc. Biol. Sci. 255(1342):37-45
PARR, C.L. \& GIBB, H. 2012. The discovery-dominance trade-off is the exception, rather than the rule. J. Anim. Ecol. 81(1):233-241. PMid:21854375. http://dx.doi.org/10.1111/j.1365-2656.2011.01899.x

PEARCE-DUVET, J.M.C., MOYANO, M., ADLER, F.R. \& FEENER JUNIOR, D.H. 2011a. Fast food in ant communities: how competing species find resources. Oecologia. 167(1):229-240. PMid:21461765. http://dx.doi.org/10.1007/s00442-011-1982-4

PEARCE-DUVET, J.M.C., ELEMANS, C.P.H. \& FEENER JUNIOR, D.H. 2011b. Walking the line: search behavior and foraging success in ant species. Behav. Ecol. 22(3):501-509. http://dx.doi.org/10.1093/ beheco/arr001

PEARCE-DUVET, J.M.C. \& FEENER JUNIOR, D.H. 2010. Resource discovery in ant communities: do food type and quantity matter? Ecol. Entomol. 35(5):549-556. http://dx.doi.org/10.1111/j.13652311.2010.01214.x

PURVIS, A. \& GARLAND, T. 1993. Polytomies in Comparative Analyses of Continuous Characters. Syst. Biol. 42(4):569-575. http://dx.doi. org/10.1093/sysbio/42.4.569

R DEVELOPMENT CORE TEAM. 2011. R: A Language and Environment for Statistical Computing. R Foundation for Statistical Computing, Vienna. http://www.R-project.org.

SCHMIDHEMPEL, P. 1991. The Ergonomics of Worker Behavior in Social Hymenoptera. Adv. Stud. Behav. 20:87-134. http://dx.doi.org/10.1016/ S0065-3454(08)60320-4

SIH, A. 1982a. Foraging Strategies and the Avoidance of Predation by An Aquatic Insect, Notonecta-Hoffmanni. Ecology, 63(3):786-796. http:// dx.doi.org/10.2307/1936799

SIH, A. 1982b. Optimal Patch Use - Variation in Selective Pressure for Efficient Foraging. Am. Nat. 120(5):666-685. http://dx.doi.org/10.1086/284019

SIH, A. \& CHRISTENSEN, B. 2001. Optimal diet theory: when does it work, and when and why does it fail? Anim. Behav. 61(2):379-390. http://dx.doi. org/10.1006/anbe.2000.1592

STEPHENS, D.W. \& KREBS, J.R. 1986. Foraging Theory. Princeton University Press, Princeton, 262p.

TRIVERS, R. 1985. Social Evolution. The Benjamin/Cummings Press, Menlo Park, 479p.

WARD, P.S. 2010. Taxonomy, phylogenetics, and evolution. In Ant ecology (L. Lach, C.L. Parr \& L. Abbott). Oxford University Press, England, p.3-17, 402p.

WESTOBY, M.; LEISHMAN, M.R. \& LORD, J.M. 1995a. Further Remarks on Phylogenetic Correction. J. Ecol. 83(4):727-729. http://dx.doi. org $110.2307 / 2261640$

WESTOBY, M.; LEISHMAN, M.R. \& LORD, J.M. 1995b. On Misinterpreting the Phylogenetic Correction. J. Ecol. 83(3):531-534. http://dx.doi. org/10.2307/2261605

WIENS, J.J., ACKERLY, D.D., ALLEN, A.P., ANACKER, B.L., BUCKELY, L.B., CORNELL, H.V., DAMSCHEM, E.I., DAVIES, T.J., GRYTNES, J., HARRISON, S.P., HAWKINS, B.A., HOLT, R.D., McCAIN, C.M. \& STEPHENS, P.R. 2010. Niche conservatism as a emerging principle in ecology and conservation biology. Ecol. Lett. 13(10):1310-1324. PMid:20649638. http://dx.doi.org/10.1111/j.1461-0248.2010.01515.x

WILSON, E.O. \& HÖLLDOBLER, B. 2005. Eusociality: Origin and consequences. P. Natl. Acad. Sci. USA. 102:13367-13371. PMid:16157878 PMCid:1224642. http://dx.doi.org/10.1073/pnas.0505858102 